Memory in Mind and Brain 
This page intentionally left blank 


\section{Memory in}

\section{Mind and Brain}

\section{What}

Dream Imagery Reveals

Morton F. Reiser, M.D. 
Paperbound edition published 1994 in the United States by Yale University Press.

Originally published 1991 in the United States by BasicBooks, a Division of HarperCollins Publishers.

Copyright $\odot 1993$ by Morton F. Reiser.

All rights reserved.

This book may not be reproduced, in whole or in part, including illustrations, in any form (beyond that copying permitted by Sections 107 and 108 of the U.S. Copyright Law and except by reviewers for the public press), without written permission from the publishers.

Library of Congress catalog card number: 93-61840

International standard book number: 0-300-06032-7

The paper in this book meets the guidelines for permanence and durability of the Committee on Production Guidelines for Book Longevity of the Council on Library Resources.

A catalogue record for this book is available from the British Library. 
For Lynn again

\author{
companion, \\ tracking on her own \\ close by and ready \\ to stop and listen \\ teach and learn \\ advise \\ edit
}

and share the game 
This page intentionally left blank 